\title{
A Review of Current Research on Hydrocarbon Production by Plants
}

H. M. Benedict

B. Inman
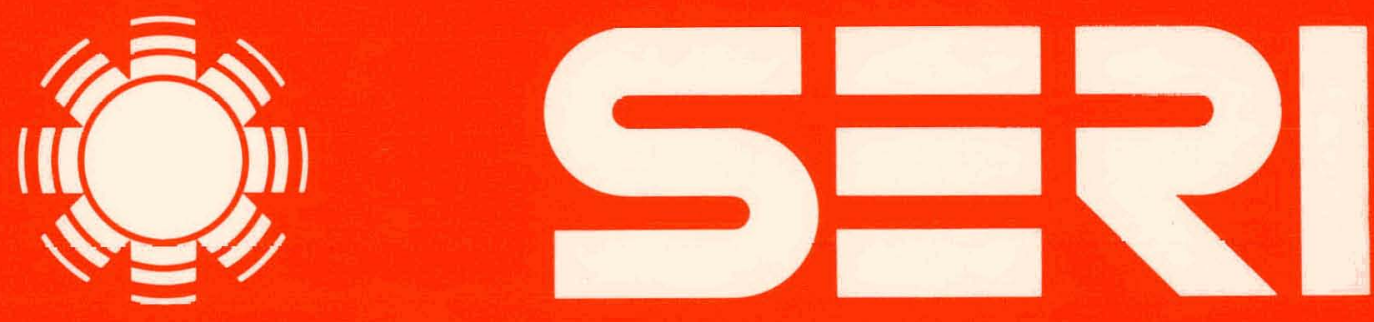

Solar Energy Research Institute

A Division of Midwest Research Institute

1536 Cole Boulevard

Gulden, Culuradu 80401

Operated for the

U.S. Department of Energy under Contract No. EG-77-C-01-4042

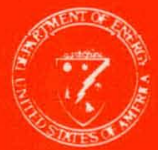




\section{DISCLAIMER}

This report was prepared as an account of work sponsored by an agency of the United States Government. Neither the United States Government nor any agency Thereof, nor any of their employees, makes any warranty, express or implied, or assumes any legal liability or responsibility for the accuracy, completeness, or usefulness of any information, apparatus, product, or process disclosed, or represents that its use would not infringe privately owned rights. Reference herein to any specific commercial product, process, or service by trade name, trademark, manufacturer, or otherwise does not necessarily constitute or imply its endorsement, recommendation, or favoring by the United States Government or any agency thereof. The views and opinions of authors expressed herein do not necessarily state or reflect those of the United States Government or any agency thereof. 


\section{DISCLAIMER}

Portions of this document may be illegible in electronic image products. Images are produced from the best available original document. 


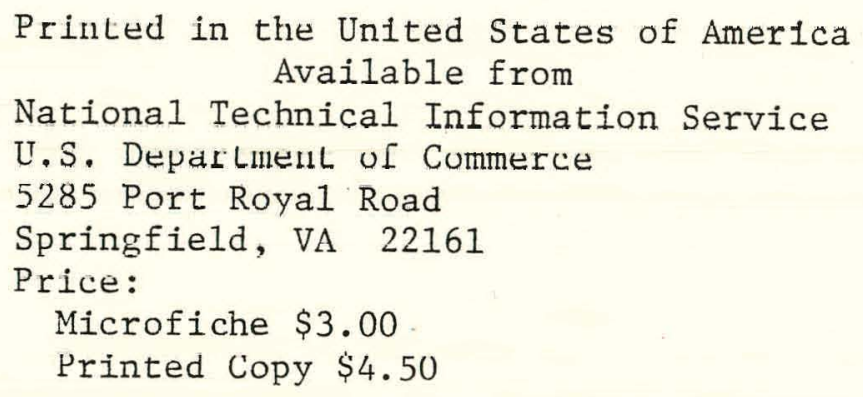

This report was prepared as an account of work sponsored by the United States Government. Ncither the United States nor the United States Department of Energy, nor any of their employees, nor any of their contractors, subcontractors, or their employees, makes any warranty, express or implied, or assumes any legal liability or responsibility for the accuracy, completeness or usefulness of any information, apparatus, product or process disclosed, or represents that its use would not infringe privately owned rights. 
SER I /TR-33-129

UC CATEGORY: UC-61

A REVIEW OF CURRENT RESEARCH ON HYDROCARBON PRODUCTION BY PLANTS

H. M. BENEDICT

B. INMAN

JANUARY 1979

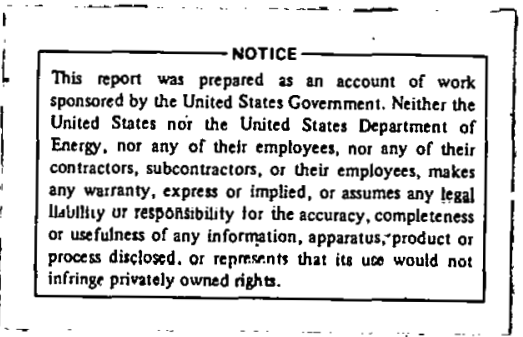

Solar Energy Research Institute

1536 Cole Boulevard

Gulden, Colorado 80401

A Division of Midwest Research Institute

Prepared for the

U.S. Department of Energy

Division of Solar Technology

Under Contract EG-77-C-01-4042 


\section{PREFACE}

This report documents work done for DOE/Fuels From Biomass Systems Branch on Task 3306 by Robert Inman, Biological/Chemical Conversion Branch of the Solar Energy Research Institute, and $H$. M. Benedict, a private consultant, Pasadena, California.

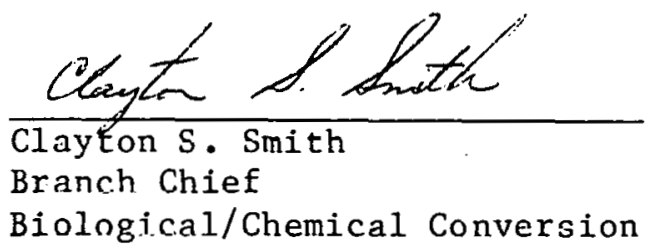

Approved for:

SOLAR ENERGY RESEARCH INSTITUTE

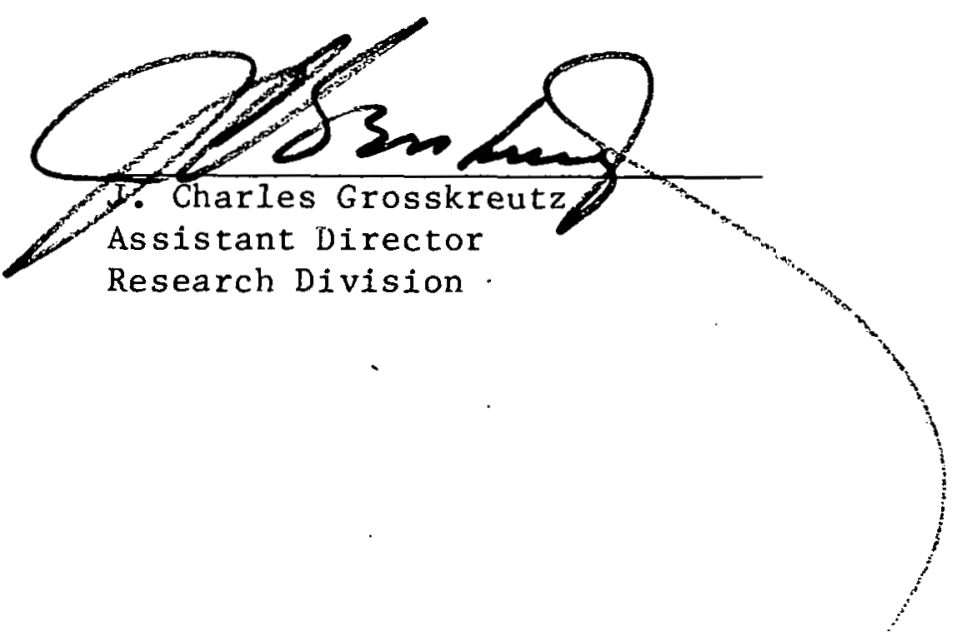


TABLE OF CONTENTS

Page

Preface ............................ . i i

Abstract . . . . . . . . . . . . . . . . . . . . 1

1.0 Introduction .................... 3

2.0 Active Hydronarhon Species Reecarch Topies . . . . . . . . 5

2.1 Scope of a Research and Development Program . . . . . 5

2.2 Species Identification and Characterization . . . . . 5

2.2.1 Survey and Selection of Test Species . . . . . 8

2.2.2 Greenhouse/Field Growth Studies ......... 12

2.2.3 Hydrocarbon Composition Studies ........ . 13

2.2.4 Market Potential Assessments ......... 14

2.3 Field Production . . . . . . . . . . . . . . 15

2.3.1 Propagation, Stand Establishment, and

Crop Management Studies . . . . . . . 15

2.3.2 Pest Control Studies . . . . . . . . . 16

2.3.3 Inductive Treatments . . . . . . . . . . 16

2.3.4 Production Plantings .............. 17

2.4 Hydrocarbon Extraction and Separation . . . . . . . 17

2.5 Biochemistry of Hydrocarbon Formation . . . . . . . 18

2.6 Genetics Research ................... 18

2.7 Environmental/Technology Assessments . . . . . . . . 19

2.8 Development of Byproduct Value . . . . . . . . . . 19

2.9 Discussion of Research Status ........... . 20

3.0 Organizations and Personnel Interested in Research

on Hydrocarbon-Producing Plants . . . . . . . . . . . 23

3.1 Federal Legislation . . . . . . . . . . . 23

3.2 State Legislation ............... . . 23

3.3 Federal Agencies . . . . . . . . . . . . . 24

3.4 States ....................... 25

3.5 Other Sources of Research Support . . . . . . . . 25

References . . . . . . . . . . . . . . . . . 29 


\begin{abstract}
This review assesses the status of research and development in the area of plants that produce hydrocarbons as a possible replacement for traditional fossil fuels. The information is meant to be used as a basis for determining the scope of a possible R\&D program by DOE/FFB.
\end{abstract}

Except in the case of guayule (Parthenium argentatum Gray), research on hydrocarbon species generally has not advanced beyond preliminary screening, extraction, and growth studies. Virtually no field studies have been initiated; hydrocarbon component extraction, separation, identification, and characterization have been only timidly approached; the biochemistry of hydrocarbon formation remains virtually untouched; and potential. market analysis has been based on insufficient data.

Research interest is increasing in this area, however. Industrial interest understandably centers about guayule prospects and is supplemented by NSF and DOE research funds. Additional support for other research topics has been supplied by DOE and USDA and by certain university systems.

Due to the infant state of technology in this area of energy research, it is not possible to predict or satisfactorily assess at this time the potential contribution that plant hydrocarbons might make toward decreasing the nation's dependence upon petroleum. However, the general impression received from experts interviewed during this review was that the major thrust of research should be directed toward the manufacture of petrochemical substitutes rather than fuel production. 
THIS PAGE INTENTIONALLY LEFT BLANK 


\section{SECTION 1.0}

\section{INTRODUCTION}

Considerable attention has recently focused on the possibility of substituting hydrocarbons produced by. plants for those obtained from crude oil. The development of likely plant sources would reduce dependence upon foreign petroleum and, through the development of new agricultural and industrial activities, create job opportunities.

Because the Department of Energy (DOE) is developing new sources of energy and attempting to decrease this country's dependence on imported energy sources, the Solar Energy Research Institute was asked to prepare a document describing the interest in developing hydrocarbon species and the research activities proposed or in progress. With this review as a background, options are to be formulated for consideration by DOE in support of an R\&D program. This report is divided into two main sections. Section 2.0 outlines the steps required to reach commercial production of a hydrocarbon from the time a plant is first found to contain such compounds. This is followed by a description of ongoing or proposed research in each step and a discussion of research interests.

Section 3.0 of the report lists the organizations and individuals who are conducting or have expressed interest in plant hydrocarbon research. An attempt is also made to indicate the amounts and sources of funding. 
THIS PAGE INTENTIONALLY LEFT BLANK 


\section{SECTION 2.0}

\section{ACTIVE HYDROCARBON SPECIES RESEARCH TOPICS}

The objective of the program under consideration is to develop hydrocarbon production from plant sources to replace hydrocarbons now imported into the United States in either their commercial form, such as natural rubber, or in the form of parent materials (crude oil).

\subsection{SCOPE OF A RESEARCH AND DEVELOPMENT PROGRAM}

Such development programs may involve a number of major research areas:

- species identification and characterization,

- domestication and field production of selected species,

- extraction and fractionation of hydrocarbons,

- biochemistry of hydrocarbon production,

- improvement of the species through genetic research, and

- environmental impact of plant hydrocarbon farming.

Representative research components within each of the major research areas are outlined in Table 2-1.

Once a species has been found to have some commercial potential, work may be started in any or all of the other research areas. Work will continue in these areas as long as the plant is used as a source of hydrocarbons. Thus research has continued on the development and management of various species producing food, fiber, and naval stores, even after such species have attained prominence as agricultural crops.

\subsection{SPECIES IDENTIFICATION AND CHARACTERIZATION}

This section outlines in detail the steps involved in a research and development program and indicates areas in which research is currently underway or for which there is an active interest in new research.

Several species have already been selected as potential hydrocarbon plants for the United States. During World War II many species were evaluated as potential rubber sources. Included were Chrysothamnus spp. (rabbit brush), Cryptostegia sp., Parthenium argentatum (guayule), Taraxacum khok-saghiz (Russian dandelion), and Solidago (goldenrod). Ot these, only guayule seems to have survived as a potential crop for commercial rubber production. The other species may warrant reevaluation as sources of other hydrocarbons. Pine trees which produce naval stores are already in plantation production. 
Table 2-1. OUTLINE OF COMPONENTS OF A RESEARCH AND DEVELOPMENT PROGRAM ON HYDROCARBON SPECIES

I. Plant Species Identification and Characterization

A. Species Screening

1. Survey and selection of test species

2. Collection of propagative material

3. Greenhouse growth studies and chemical production analysis

4. Chemical extraction/fractionation/identification

B. Species Evaluation

1. Market value assessments

2. Feasibility for field production in the United States

3. Land availability studies and systems andilyses

C. Bench-Scale Extraction/Separation Studies

II. Field Production

A. 'Propagation and Stand Establishment

1. Direct seeding

a. Seed production studies

b. Seed germination studies

c. Seed handling and cleaning methods

d. Seedling crop establishment

2. Seedling transplant

a. Seed germination studies

b. Seed-bed preparation and management

c. Spedling handling and transplanting

d. Transplant crop establishment

e. Tissue culture/single cell studies

3. Cuttings

a. Cuttings preparation

b. Cullings handling and etorage

c. Planting and establishment

4. Planting equipment development

B. Crop Management Practices

1. Fertilization requirements

2. Irrigation requirements

3. Irrigation/fertilization techniques

4. Weed control requirements

5. Insect/disease control requirements

6. Inductive treatments and techniques

a. Actlve compounds acreening

b. Rate of application

c. Time and frequency of application

7. Economic assessments and evaluations

8. Energy consumption assessments

C. Harvesting

1. Time of harvest

2. Length of rotation period (coppicing species)

3. Crop storage requirements

4. Integrated product harvesting systems

5. Specialized equipment development

6. Tapping techniques and systems

7. Economic assessments 


\section{Table 2-1. (Continued)}

D. Production Plantings

1. Installation/operation of pilot farms and LEFs $\dagger$

2. Demonstration farms

III. Product Extraction and Separation

A. Materials Handling Techuiques

B. Pretreatment Requirements

1. Mechanical/physical

2. Chemical

C. Mechanical Extraction Techniques

D. Solvent Extraction Techniques/Solvent Recovery

E. Fractionation and Separation

F. Economic/Energetic Assessments

G. PDU/LEF Operationst†

H. Demonstration Operations

IV. Biochemistry of Plant Hydrocarbon Production

A. Blochemical Pathway Identification

B. Pathway Modification and Control

V. Genetics Research

A. Breeding for High-Yielding Strains

B. Genetic Control of Hydrocarbon Production

VI. Environmental Assessments

TLEF = Large Experimental Farms

$\dagger \dagger P D U / L E F=$ Process Demonstration Units/Large Experimental Facilities 


\subsubsection{Survey and Selection of Test Species}

Before a species can be evaluated as a potential hydrocarbon producer, standardized methods are needed to identify the hydrocarbons present and to determine their yields relative to the dry weight of the plant.

At the Lawrence Berkeley Laboratories at the University of California, Berkeley, Melvin Calvin and his group have developed a procedure for the quantitative analysis of latex-bearing plants, including Euphorbia lathyrus. The method involves solvent extraction of the dried, ground plant with acetone, then benzonp, and then methanol and hexane. The compounds in the various fractions are determined by gas chromatography and mass spcctrophotometry (GCMS). Calvin's analyses of the hydrocarbons present in severa1 species of plants are reported by Nielsen et al., 1977, and are discussed in detail in this section.

At the Northern Regional Research Center, Agricultural Research Service, USDA at Peoria, I11., R.A. Buchanan and his coworkers have been screening latexbearing and non-bearing plants for useful hydrocarbons. They also have developed a procedure for estimating the nature and amounts of hydrocarbons produced in various species. Their procedure (Buchanan, 1976) is similar to that used by Calvin's group and is presented in Figure 2-1.

Lawrence Berkeley and the Northern Regional Research Center are the only laboratories making a concerted effort to screen numbers of species for hydrocarbon content. The Berkeley group has concentrated mainiy on lacexproducing plants native to the arid southwestern parts of the United States. This work has been reported in several publications, including lálvin (1974) and (1977) and Nielsen et al. (1977). These efforts have concentrated primarily on species of Euphorbia, which are in the same family as Hevea braziliensis, the rubber tree. They have also reported on Asclepias (mi 1,kweed). Most of the work has been done on Euphorbia lathyrus, an annual found in the southwestern United States.

Buchanan's studies at Peoria (USDA) have covered a much wider range of species. Before embarking on their program, however, they established a preliminary evaluation procedure based on probable species adaptab111ty and crop potential; probable biomass yields; and hydrocarbon, oil, crude protein, and fiber composition (Buchanan et al., 1976). In all, about 300 species have been evaluated (Buchanan et al., 1976, 1977, 1978). Although most species were native to or at least found in the vicinity of Peoria, Ill., several species known in other parts of the United States were included that had been shown earlier to have a high hydrocarbon content. As a result of the screening program, which considered both agricultural production potential and hydrocarbon content, the following species were determined to have the greatest potential for development: 


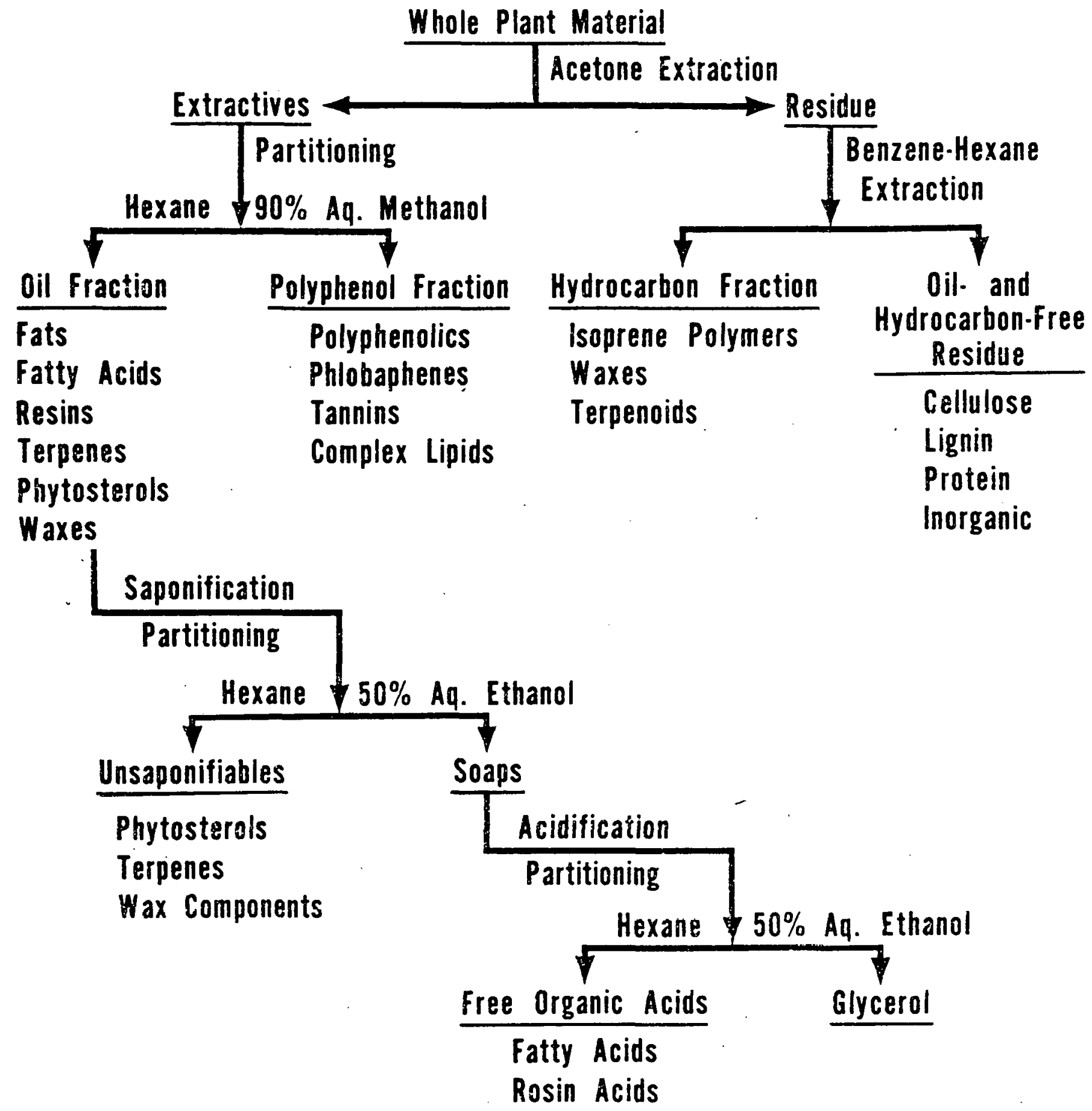

Figure 2-1. GENERALIZED SCHEME FOR THE EXTRACTION AND ANALYSIS OF PLANT HYDROCARBONS (USDA, PEORIA, ILL.). 


Parthenium argentatum
Chrysothamnus nauseosus
Solidago spp.
Larrea tridentata
Sassafras albidum
Euphorbia $\frac{\text { lathyrus }}{\text { Asclepias }}$ spp.

guayule

rabbit brush

goldenrod

creosote bush (resins)

sassafras oil

euphorbia

milkweed

According to Buchanan (1978), field work on the domestication of these species could be started immediately. Much work has already been done on guayule (Hammond and Polhamus, 1965; Anon., 1977), and commercial field plantings are in order.

In the course of their work the USDA group has emphasized the importance of considering products other than the hydrocarbons in evaluating a species as a potential crop. The total biomass may be of value as a suires of crude fiber, and the protein content may enhance the value of the residue as livestock fecd after hydrocarbon removal. The USDA group has also decermined ilial suiue plants have whole-plant oil contents of $5 \%$ and higher. If the whole plant were extracted, oil yields could exceed by several times the yield of conven= tional oilseed crops (Buchanan et al., 1978). Another feature of the work at Peoria is the discovery that certain grasses contain gutta. Among them are Agropyron repens (quack grass), one of the worst weeds of the central United States, and Elymus canadensis (Canadian rye grass) (Buchanan et al.,1978).

The Diamond Shamrock Co. is interested in low molecular weight hydrocarbons and is financing a program with the office of Arid Land Studies, Universily of Arizona, in which native desert species will be screened for hydrocarbon production. This will be followed by studies on effects of environmental factors in growth chambers and on methods of extraction and by development programs with the most productive species. Projected funding is $\$ 2$ million for a five-year period.

Although the USDA and the Berkeley laboratories have done the mafority of the work in screening plants for hydrocarbons, the U.S. Dept. of Agriculture and the University of Arizona have developed an oll seed crop based on Simmondoia chinensis (jojoba), a llabive plant of the Arizona decert. The seets nf this plant contain an oil that can be substituted for sperm whale oil. At the present time several thousand acres have been planted in California and Arizona. Because the oil is in great demand, especially in Japan, this plant is well on the way to providing the basis for a new agricultural industry (National Academy of Sclences, 1975; Sherbrooke and Haase, 1976; Jojoba Happenings, June 1978).

Jojoba already has passed the field plot and demonstration stage in the United States. It is an established, if sma11, industry in its own right, and production is increasing. Foreign countries have also shown an interest in 
this crop. The Unilever Corporation has established test plots in Turkey and Africa. Plantings have been made in the state of Rajasthan, India (Weber, 1978), and efforts are being made to develop jojoba plantings in Haiti. Successful plantings are reported in the northern Negev Desert in Israel, and local growers have established plantings near Cape Town, South Africa (Jojoba Happenings, June 1978). As a whole oil substitute, jojoba oil could be developed for a variety of industrial uses.

Another potential oil crop, buffalo gourd (Cucurbita foetidissima), grows wild in the arid lands of the western United States. Its seeds have been found to contain as much as $34 \%$ oil, although the nature and commercial potential of the oil have yet to be determined. In addition, buffalo gourd produces a tap root that may weigh as much as $145 \mathrm{~kg}(310 \mathrm{lb})$ after three years. More research is needed on seed oil quality and applications (Advisory Committee on Technical Innovation, 1975).

In studies on American deserts conducted at the University of Texas, the predominance of creosote bush (Larrea tridentata) and its high content of aromatic compounds led to a study of the nature of the compounds and the possible use of this plant as a source of industrial chemicals. The compounds were found to be mostly phenolic, and the leaves contained as much as $15 \%$ organic-solvent extractables. The Mexican Government has initiated studies to develop commercial use of these compounds. They appear to be of some value as plasticizers and may contain some antibiotics. Studies are in progress on the Larrea growth responses to clipping, with the hope of harvesting the plant in the wild and then allowing it to regrow before harvesting it again. Larrea is a very slowly growing shrub, and large acreages of wild plants must be available for commercial production. No attempt has been made yet to cultivate the plant. Some studies are being made on propagation to provide experimental material (Mabry 1978). The cost of the aromatic compounds, practical methods of extraction, etc., have not been estimated, nor have the effects of irrigation or fertilization been studied. Much more information is needed about the compounds and their potential industrial uses before the value of Larrea as a hydrocarbon plant can be determined.

The island of Puerto Rico has a subtropical climate, and there are some areas on the south side of the island that are fairly dry. Preliminary investigations have revealed some 65 species of plants there with potential for development as hydrocarbon crops. Enough is known about 35 of these species to warrant investigations of methods of propagation and studies on the effects of water, nutrient supply, and temperature on hydrocarbon production. Investigators believe that field plots of two promising species (Eupliorbla lactea and Calatropis procera) should be established.

The University of Puerto Rico, Center for Energy and Environment Research, has submitted a research project proposal entitled "Evaluation of Hydrocarbon Bearing Plants as a Renewable Energy Source" with Alex Alexander as principal investigator. They propose to screen the 65 species for the amounts and types of hydrocarbon pruduced. Over a four-year period they then would develop methods of propagation, cultural practices, etc., with greenhouse and field 
experiments. This project would add a fourth lucation for screening of many species. Since this is a new area for such evaluations a whole new type of plant would be brought under surveillance, and an additional center of expertise would be developed.

Thus far, this section has dealt with hydrocarbon production by higher plants. For many decades the lower plants, especially algae, have been considered as potential sources of food protein and possibly fuel (Burlew, 1953). A species of diatom, Phaeodactylum tricornutum, was found to have particularly strong potential as a food or fuel source. Its potential as a fuel source ranks especially high because it may contain as much as $81 \%$ lipids, based on dry, ash-free plant weight. Pilot plant cultures of this diatom have been grown in Hawaii in nutrient-supplemented sea water. Under the system used, production equivalents of 23.97 tons of protein, 13.28 Luls of lipids, and 0.12 ton of carbohydrates per acre were claimed. This is a total production of almost 38 tons of dry matter per acre-year, a reported yield much greater than that obtained from higher plants (Raymond, 1977).

\subsubsection{Greenhouse/Field Growth Studies}

Greenhouse and field-plot studies are a logical sequel to species screening. Several of the more promising hydrocarbon species are currently in this stage of investigation with guayule receiving most of the attention.

Research at the Los Angeles County Arboretum, primarily with guayule breeding, is also concerned with the treatments required for acceplable levels of sced germination (Hansen, 1978). As a result of pest problems that have ar1sen lu seedling production, Hansen's research has been expanded to include pestliclue evaluations. Similar studies are underway at the University of Arizona, where a breeding program and plant physiology studies are in progress (Rubis, 1978). These studies overlap to some extent those conducted during the Emergency Rubber Project, 1941-1954 (Hammond and Polhamus, 1965).

The Firestone Tire and Rubber Company has constructed a greenhouse near Fort Stockton, Tex., for guayule growth studies (Glymph, 1978), and physiological studies on growth and rubber production are in progress in Israel at the Ben Gurion University of the Negev (Schechter, 19/6).

The Border Commission has awarded the Agricultural Development Committee of Texas A \& M University a $\$ 100,000$ grant for a technological evaluation of guayule production. Field plots have been established at the agricultural experiment station at E1 Paso, Tex., under the direction of James Tipton. Field plots have also been installed at New Mexico State University at Las Cruces under the supervision of Wayne Whitworth. 
Other potential hydrocarbon species are receiving attention. The Berkeley group has established field plots of Euphorbia lathyrus at a field station near Oceanside, Calif., and crop management and production studies are underway. Greenhouse growth studies of this species are being conducted on the Riverside campus. Diamond Shamrock is sponsoring growth chamber studies of Euphorbia and other species at the University of Arizona (Office of Arid Land Studies), which should supplement the research in California.

The research proposed by Alexander in Puerto Rico would also include greenhouse and field-plot studies, and the USDA has subuitted a proposal to DOE for greenhouse and field studies on guayule, jojoba, and creosote bush in the southwest. Studies on creosote bush are relatively recent, and few details are available. Greenhouse and field studies have been started at the University of Texas (Mabry, 1978) on this species, however, and will supplement the studies at the University of Arizona sponsored by Diamond Shanrock.

Plantings of buffalo gourd have been made in Lebanon and by the University of Arizona near Tucson. Bemis et al. (1978) have reported oil seed yields of 1,800 pounds per acre-year during the third year of growth.

\subsubsection{Hydrocarbon Composition Studies}

The final step in screening is to determine in some detail the hydrocarbons present and the relative amounts of each by solvent extraction and GCMS. In some instances, however, because of specific interest in a given hydrocarbon other potentially valuable compounds may be overlooked. For example, while the guayule plant produces large amounts of benzene-soluble hydrocarbons (rubber), it also produces considerable quantities of acetone-soluble compounds (resins) that have been largely neglected. There may well be compounds present in the acetone fraction of high commercial value that would enhance the economis. feasibility of guayule as a ciup. Consequentiy, the Institute of Polymer Science at the University of Akron in Ohio has been awarded an NSF grant to investigate the resins found in guayule. The two-year study will develop information on the resins and their thermal characteristics.

The group at Berkeley (Nielson et a1., 1977) used a standard method of extraction in determining the hydrocarbon content of various latex-bearing plants. They have since improved this method, as described in a draft report to DOE (Otvos and Calvin, 1978).

The work at Peoria under Buchanan (1977) has also characterized the compounds present based on their solubllity. To evaluate their usefulness as replacements for oil products in a chemical industry, the individual compounds and their physical properties should be identified. Except fur the work on guayule resins and studies on jojoba oil, little work is being done in this area. 


\subsubsection{Market Potential Assessments}

Estimates have been made for the production, extraction, and purification of guayule rubber based on assumed yields of rubber per acre. Assuming rubber yields of 400 to 500 pounds per acre per year over a 5-year period, Firestone estimated extraction costs from 20.5 to $25 \mathrm{~d} / \mathrm{lb}$. The value of resins and pulp as byproducts were also calculated as 12 to $20.5 \$ / 1 b$ rubber. Considering total capital outlay of $\$ 35$ to $\$ 50$ million, the credited costs for rubber would vary from 29 to $54 \mathrm{~d} / 1 \mathrm{~b}$. The projected 1985 price of rubber varies from 54 to $63 \mathrm{~d} / \mathrm{lb}$. In order to return $12 \%$ on the investment, the price would have to be 46 to $78 \$ / 1 b$. These are estimates for 1985; at that date guayule production may or may not be protitable (Glymph dud Niven, 1978).

Calvin estimates a production of hydrocarbon from Euphorbia is equivalent to 8 harrels of uil (about 1 ton) per acre at a total production cost of $\$ 20$ per barrel. At present this could not compete with crude o1l, which is selling for about $\$ 14$ a barrel. If yleldy could be increased and production costs lowered a more favorable comparison might be made (Calvin, 1978).

Raymond (1978) estimates that cultures of the alga Phaeodactylon tricornutum in Hawaii would produce the equivalent of 150 barrels of oil per acre-year and that an area of 200 square miles eventually could supply all of Hawaii's crude oil.

Jojoba plantations are being established in southern Calffornia and Arizona. One private grower is planning 14,000 acres in southern California. Since the Japanese are buylng all the uil availablc, thic plant seems to he approaching full crnp status and its market value is no longer in question. Stubblefield and Wright (1977) have provided information on the economic feasibility of jojoba culture.

Estimates were made for the production of Buffalo gourd seed in Syria and Lebanon where harvesting and weeding was done by hand and irrigacton was dune three to lour times the flist yedi and once or twice the second year. If the development costs are prorated over a ten-year period, the cost of producing seed with a yield of $1800 \mathrm{lb}$ per acre would be $5.2 \$ / 1 \mathrm{~b}$. The seed is estimated to he worth about $6.1 \mathrm{d/lb}$ (the equivalent of cotton seed). If yields of $2400 \mathrm{Ib}$ per acre are obtained, the cost per pound would drop to about 4.5 $\$ / 1 b$. This includes land rental, water costs, and an $8 \%$ return on investment (Wright, 1974).

The Energy Resources Conservation and Development Commission of. the State of California is studying the economic potential of guayule and Euphorbia in that state. The program will identify and establish plantings of guayule and Euphorbia at favorable sites. The chemistry of the formation of the various hydrocarbons in these latex plants will be outlined and the chemicals produced will be identified. At the same time, the possibility of converting these 
compounds into industrial chemicals and fuels with established uses will be explored. The engineering and economics of an industrial plant to extract the compounds will be evaluated. Industries presently using these compounds will then be asked to help in establishing joint projects and programs.

An economic analysis of the hydrocarbon compounds produced by Euphorbia is being done by SRI International based on the work of Calvin's group.

\subsection{FIELD PRODUCTION}

At present, field production studies are limited to guayule, jojoba, buffalo gourd, and Euphorbia.

\subsubsection{Propagation, Stand Establishment, and Crop Management Studies}

Studies on guayule are in progress at the Los Angeles County Arboretum and the University of Arizona as aids to providing and maintaining plants for the breeding programs rather than to establish field stands. Some studies will seek to develop a method for making seed into pellets, which would make direct seeding in the field an easier task. Rubis at the University of Arizona and Hansen at Los Angeles are conducting studies on pollarding of guayule; however, these studies are incidental to a breeding program.

In actuality all of the fleld production studies are largely incidental or consist primarily of field plots where fertilization and irrigation can be studied on an experimental basis. No large-scale, well-defined research programs are investigating the cultural needs of guayule, jojoba, buffalo gourd, or Euphorbia during their entire growth and development. For example, before a crop such as guayule can be proven to be appropriate for a given area, it is essential to know its water requirements. Yet there are no projects intensively investigating this problem. The same can be said for the other crops that have already shown promise. The USDA proposal for field research on jojoba, guayule, and creosote bush in the Southwest would address these needs.

As an aid in obtaining as many clones as possible from a single, especially desirable plant and as an aid in classical breeding programs, methods have been developed whereby individual plants can be derived from single cell cultures, each with the genetic make-up of the parent cell. Such tissue culture studies are being conducted on guayule and jojoba by Dr. Toshio Murashige at the University of California, Riverside, supported by an NSF grant. Dr. Schechter at the Ben Gurion University of the Negev, Israel, is also directing work on tissue culture for jojoba and guayule. Interest in conducting further such research has been expressed by Calvin (Berkeley) on 
Euphorbia and by Hansen at the (Los Angeles County Arboretum) on guayule. Native Plants, Inc., of Salt Lake City has submitted a proposal to DOE entitled "A Demonstration of Economic Feasibility of Plant Tissue Culture" requesting $\$ 123,000$ for two years for work on guayule and jojoba.

\subsubsection{Pest Control Studies}

No specific programs have been initiated or proposed on pest control problems in hydrocarbon plants, but weeds, plant diseases, and insects have been problems where breeding is in progress, and incidental studies on these problems are being done by Hansen at the Los Angeles County Arburetum and by Rubis at the University of Arizona.

In developing the use of paraquat to increase the oleoresin content of pine trees (see Section 2.3.3) it was found that paraquat treatments increased the tree's susceptibility to bark beetles, which often killed large proportions of the treated stands. In general more trees have been killed as a result of insect infestation following paraquat treatment than by any other agent. Considerable work has been done in the southeastern United States to control such infestations (Lightwood Kesearch Coordinating Council Session II Meetings, January' 1976, Jacksonville, Fla.).

\subsubsection{Inductive Treatments}

It has been found that treatment of carotenogenic plant tissues with growth regulating or related compounds increases production of tctraterpenoids, for example, lycopin in lemon rinds. It has been postulated that similar treatments might be used to increase hydrocarbon production in such plants as guayule, Euphorbia, and even Hevea. Tests with guayule have produced ralliei spectacular results. In vigurvusly growing planto four to aight mnnths nld, two- to sixfold increases in the rubber content were obtained (Yokoyamla et al., 1977). Yokayama (1978) is continuing these scudles wlll Eupliurbia and guayule and feels confident that compounds can be developed to produce similar effects in any hydrocarbon-producing plant. Accurding to theory, plants contain genetic tactors which depress ur inhibit the formation of hydrnrarbons; the treatments mitigate or inhibit the the effects of these factors. If repeatable and consistent, these experiments could have a tremendous impact on the hydrocarbon potential of many specles and could change the method of culture. However, the experimental results should be treated cautiously until studies on multiple plant treatments and lates of application cetablish accuract dose-response curves. Such research should be given high priority.

Additional information is needed on the molecular weight and other physical characteristics of the rubber formed via bioinduction treatments. It is also not known whether rubber is formed at the expense of other compounds, such as 
resins and carbohydrates, that might affect a plant's 1ongevity, growth rate, etc. Thus, bioinduction should be tested on mature plants. If consistent results continue to be demonstrated under laboratory conditions, field tests should be started.

Another instance of bioinduction that has been verified and supports the results on guayule is the application of paraquat, a growth-regulating herbicide, to pine trees to increase the yield of oleoresins. Applying a $2 \%$ to $8 \%$ solution of paraquat to a wound on the trunk of a tree induces resin formation extending from the wound to the center of the tree and upward for as much as $15 \mathrm{ft}$, depending on the species of pine. This section becomes saturated in about two years (Collier, 1976), producing a two- to fivefold increase in the oleoresin content of the wood (Drew and Roberts, 1977; Stubbs, 1977).

Studies to date have shown that (1) the increase in oleoresins is indeed real and can be repeated easily; (2) the increase in oleoresins appears to occur at the expense of carbohydrates, possibly proteins; and (3) the chemical composition of the oleoresins is not greatly changed by the treatment and consists of resins, terpenes, and turpentines. Assuming a threefold increase in oleoresin yield and that one third of the trees currently grown for oleoresin production were treated, the total increase would amount to $206,229,0001 \mathrm{~b}$ of tall oil resin and $11,564,000$ gallons of turpentine. These increases would correspond to $36 \%$ and $52 \%$, respectively, of the total yield of the two materials during the crop year 1975-76. While the percentage of displaced petroleum represented may be small, the absolute amounts of tall oils and turpentine are significant. Research on the effects of paraquat on oleoresin production was conducted at the Southeast Forest Experiment Station, Aiken, S.C.; Olustee, Fla.; Georgia Institute of Technology; and Battelle Memorial Institute, Columbus, Ohio.

\subsubsection{Production Plantings}

Production plantings of jojoba have been made in Arizona and Southern California by private interests. The office of Arid Land Studies in Arizona has established demonstration plots of buffalo gourds. The Goodyear Tire and Rubber Company has made a small demonstration planting of guayule near Phoenix, Ariz., and the Firestone Rubber Company is beginning a large planting of guayule (2000 acres) for demnnstration and actual productiun. The studies in Puerto Rico if undertaken would establish demonstration plots.

\subsection{HYDROCARBON EXTRACTION AND SEPARATION}

Centro De Investigation En Quimica Aplicada in Salti11n, Mexico, has bcen investlgating both grinding and solvent (acetone) extraction methods for guayule rubber for several years under the direction of Enrique Campos Lopez. 
The Firestone Natural Rubber and Latex Company is investigating a solvent extraction method in which the ground plant material is first extracted with acetone to remove the resins. The remaining pulp is dried and treated with hexane to extract the rubber. The hexane is stripped and recovered. These are the only current research efforts on rubber extraction methods.

Considerable work has been done on the cxtraction of the wax and oils from jojoba. One effort supported by the Tribal Council of the Arizona Indians, has developed a satisfactory commercial process.

Extraction processes for Euphorbia and other lydrocarbon plants are in pre1.iminary stäges of development.

\subsection{BIOCHEMISTRY OF HYDROCARBON FORMATION}

This area of research has received little concerted attention to date. Current research on bioinductive treatments of guayule and Euphorbia, however, can be expected to provide information concerning the genetic and physiological factors that control hydrocarbon formation in plants. Additional emphasis on this question seems warranted at this time.

\subsection{GENETICS RESEARCH}

Ao mentioned parlier, genetics research or breeding programs designed to develop more productive varieties of guayule are underway at the Los Angeles County Arbortum and the University of Arizona. Selection criteria used by Hansen at the Los Angeles Arboretum include plant vigor, growth rate, and rubber content. In working will guayule and other species of Parthenium. Hansen has discovered a correlation between leaf hair characteristics and rubber content of individual plants; this relationship 1 s belng used as a tool in selecting plants for sludy. The work i.s funded by the NSF.

At the University of Arizona Rubis has used the criteria for selection used by Hansen, with an additional criterion of cold tolerance. There are vast areas in the United States that supply all growth requirements for guayule except favorable temperatures. If more cold-tolerant varieties could be developed, the areas in which guayule could be grown would be greatly increased. Rubis' program was funded initially by the NSF but is now supported by the Four Corners Commission. Genelics research on other potential hydrocarbon species has not been started. 


\subsection{ENVIRONMENTAL/TECHNOLOGY ASSESSMENTS}

In the development of any new industry there are environmental, economic, and sociological effects. Consequently the Midwest Research Institute, in cooperation with the Office of Arid Lands Studies at the University of Arizona, has begun a project entitled "A Technology Assessment of the Commercialization of Guayule: Domestic Rubber Source of the Future". This study will examine the technical, economic, social, and national forces that might stimulate development of this technology; the possible impacts of commercialization; the alternative approaches open to government and the private sector; and the results that might be expected from exercising different options.

\subsection{DEVELOPMENT OF BYPRODUCT VALUE}

Very often the value of a single substance found in a plant is not great enough to make plant production profitable. Thus although the compound of direct interest may bring the greatest returns, economic feasibility may hinge upon the sales value of secondary products. In the economic analysis of guayule production and processing, it is estimated that the resins extracted will bring about $20 \phi / 1 b$ and the pulp about $1-2 \phi / 1 b$. Work is being done at the University of Akron on the nature and physical characteristics of guayule resins. Work is also underway at the Jet Propulsion Laboratory in Pasadena, California to convert guayule bagasse (pulp) into a desirable fuel by means of pyrolysis (Bauman, 1978). Some attempts have been made to convert the leaves into stock feed. Guayule is a very prolific seed producer, and the possibility of the seed containing useful hydrocarbons (oils) should be investigated.

Jojoba seed meal appears to have promise as a stock feed as it is fairly high in protein (McGinnies, 1978). However, some toxic material seems to be present in the meal that could comproulse its utility as an animal feed. The nutritive value of buffalo gourd meals is being investigated at the office of Arid Lands Studies in Arizona.

The conversion of all vegetative residues into a more usable fuel seems highly desirable. Commercial guayule production would result in a huge tonnage of bagasse. Various paper cumpanles have shown interest in this material. Hydrocarbon production from Euphorbia lathyrus would also produce large amnunts of bagaece, as would must of the annual and scrubby plants mentioned earlier. 


\subsection{DISCUSSION OF RESEARCH STATUS}

A review of the work and interest in hydrocarbon plants indicates that a great many plants contain desirable hydrocarbons in amounts warranting further investigation. Nevertheless, there are only a relatively few species about which enough is known to justify field plantings; these are discussed individually in section 2.2.2. There seems to be a wide gap in information concerning what hydrocarbons the plants may produce and their potential industrial application and market. More details are needed on the exact chemical nature of the hydrocarbons found in latex, seed, and other plant parts. The studies at the University of Akron on guayule resins, at the University of California, Berkeley, and at the USDA Northern Research Laboratories, Peoria, are steps in this direction. Information on such cumpuunds and thcir uce in industry should be examined to provide both a background and future direction for hydrocarbon plant research and development efforts.

Three laboratories are interested in species screenlng. Initial screens have uncovered many species of unusually high hydrocarbon content. Little interest has been shown in basic plant physiological studies needed to determine the factors affecting the amount and nature of the hydrocarbons produced.

One fact made apparent throughout this review is the unnecessary repetition of work at different locations. Not enough attention has been paid to original publications on guayule by the new workers in the field, and too much reliance has been placed on review articles such as that by Polhamus and Hammond (1965). As excellent a review as this was, it could not give the details of or descrihe all the published experiments conducted during the Emergency Rubber Project. For this reason some central coordination activity seems advisable.

of all plants considered to date, several demonstrate potential for supplying hydrocarbon chemicals to substitute for those now ublained from oil. $\Lambda$ technique that seems to have immediate promise is the b1o-1nducliul of hydrocarbons by paraquat in pine trees. While optimum treatments for different ages, conditions, and other site-specific characteristics have not been determined, field trials are continuing toward this end. More studies are needed on the methods of treatment and the biochemistry of oleoresin formation. This could lead to even higher oleoresin yields or perhaps to a change in the type of hydrocarbons formed.

Guayule probably ranks next in order of immediate availability, partially because of the information accumulated during the Emergency Rubber Project. The immediate need is to establish large demonstration plantings to provide sufficient material for growth, harvesting, extraction, and purification trials. There remain some important questions, many of which were asked by Benedict (1977) in the Proceedings of the Second Interuational Guayule Conference held in Saltillo, Mexico, in 1977. Since that paper was presented, the work on bioinduction of rubber in guayule by Yokoyama et al. (1978) has 
appeared. These results are so spectacular that, if they can be duplicated in field experiments, guayule will immediately become a profitable crop.

Euphorbia culture today is at approximately the same stage of development that guayule culture had reached at the beginning of the Emergency Rubber Project. Research on stand establishment, growth, and production in experimental and field plots remains to be done; however, the plant shows enough promise to make such studies worthwhile. Large-scale methods of latex extraction and purification will have to be developed. Fortunately these studies can proceed simultaneously. Genetic studies should be started to determine existing variability and selection of desirable factors should begin.

As far as production per acre is concerned, Raymond's (1977) culture of diatom yielded much more than any of the higher plants studied. The yields should be analyzed carefully under field conditions, and the nature of the lipids should be determined. Also, experiments are needed on the effects of variations in nutrient solutions and all other features of diatom culture.

Jojoba. seems to have progressed into a true commercial crop. Where at first it was harvested from wild plants, now plantations of hundreds of acres are being grown. The processors are utilizing all of the jojoba crop that is grown at present. While further research is undoubtedly of value, this crop is sufficiently established so that special stimulus is not needed to ensure that the plant becomes and remains a commercial crop.

In summary, there is research in progress and abundant interest expressed in screening plants for hydrocarbon production and in characterizing the hydrocarbons produced; however, there is a lack of research and interest in the physiology and agronomy of plants that show promise. This is also generally true for the plants that have proceeded well beyond the screening stage. There is an active interest in bioinduction studies but little activity or interest in testing these practices in the field, despite their importance and potential. There 1s little research in progress or interest in the biochemical steps that occur in hydrocarbon formation but considerable interest in tissue culture and single cell culture, plant breeding, and genetics. In other words, the glamorous phases of hydrocarbon production are being investigated, but the applied phases such as the agronomy of crop production need the stimulus that might be provided by additional funding.

Overall, plant hydrocarbon research is in a fledgling stage, such that estimates or predictions of potential hydrocarbon yields in terms of equivalent barrels of oil, or costs per barrel-equivalent, are rendered meaningless by the vast technological uncertainties that now prevail. Sentiments of the pioneer investigators currently working in this field, however, suggest that the primary use potential lies in the production of substitutes for petroleumderived industrial chemicals. The ligno-cellulosic residues from plant hydrocarbon processing, conversely, could either be used as a fuel by the processor or sold for use as a fuel. 
THIS PAGE INTENTIONALLY LEFT BLANK

22 


\section{SECTION 3.0}

\section{ORGANIZATIONS AND PERSONNEL INTERESTED IN RESEARCH ON HYDROCARBON-PRODUCING PLANTS}

This section summarizes the activities and interests of government agencies and legislatures and of industry in research on hydrocarbon production by plants.

\subsection{FEDERAL LEGISLATION}

Two bills before the U.S. Congress are designed to support research and development of hydrocarbon-producing plants. A bill passed by the Senate (S. 1816), designated "Guayule Rubber Demonstration and Economic Development Act," would authorize expenditure of $\$ 30$ million over a five-year period for research and development of a guayule rubber industry. The Department of Commerce would have responsibility for activities under this bill, which concerns only the commercialization of guayule.

A bill before the House (H.R. 12559) differs somewhat from S. 1816 and is entitled "Native Latex Commercialization Act of 1977". This bill provides for the development of economically feasible means of culturing Parthenium (guayule) and other hydrocarbon-containing plant species for extraction of latex and other products. The funds are to be made available to the Department of Agriculture. The House bill has been unanimously recommended for approval by the House Committee on Science and Technology; however, it does not go into effect until fiscal year 1980. Both the Senate and House bills focus on domestic rubber production and do not provide for the development of other plant hydrnrarhons.

\subsection{STATE LEgISLATION}

A bill before the California State Assembly provides for the establishment of a pilot guayule development program, which includes establishing of ten test plots in suitable growing areas in the State of California. Also 1ncluded is the development of a breeding and selection program to improve rubber yield; expand insect and disease resistance; determine effects of irrigation on plant growth, rubber yield, and survival potential; determine economic methods for obtaining acceptable stands; study nursery stock; and direct seeding methods. The program would extend from the autumn of 1978 until January 1, 1982. The original bill included an appropriation of $\$ 2$ million; however, it was later amended to require the California Director of Food and Agriculture to seek federal funding to carry out the provisions of the Act. This bill has not yet been approved by the Assembly. 


\subsection{FEDERAL AGENCIES}

DOE is continuing to support limited research on hydrocarbon species. A fiveyear study to develop the procedure for treating pine trees with paraquat has been funded in the amount of about $\$ 620,000$. This work is headquartered at the Southeastern Forest Experiment Station in Aiken, S.C., under the direction of Jack Stubbs.

Calvin's work at Berkeley on Euphorbia has received about $\$ 35,000$ in support from DOE. Proposals for additional research on hydrocarbon species development have been submitted to DOE by various research institutions.

The Department of Agriculture (USDA) is supporting the work of Buchanan et al. at Peoria, lll., on screenlng plants fur hydrocarbon production; the work of Yokoyama at the Fruit Laboratory in Pasadena, Calif., on the bioinduction of hydrocarbon formation; and a project to assemble and catalogue the reports und materials accumulated by the Emergency Rubber Project.

Through the Four Corners Commission the Department of Commerce (DOC) is supporting a breeding program on guayule at the University of Arizona in the amount of about $\$ 100,000$ a year and field plot studies with guayule at New Mexico State University under the direction of Wayne Whitworth. Similar work is being supported by this commission in Nevada.

The Four Corners Commission supported the Office of Arid Land Studies (OALS) of the University of Arizona in establishing a collection of guayule-related material as a part of the larger project mentioned in the previous paragraph.

The Border Commission of DOC is supporting an evaluation program of guayule at the University of Texas.

The National Science Foundation (NSF) is supporcing a three-year guayule breeding program at the Los Angeles County Arboretum under the dlreclivi of George Hansen and part of the work of Yokayama at the USDA Fruit Laboratory.

The NSF is also funding a technology assessment program of guayule in the amount of $\$ 260,000$ over a 15 -month period. The work is being done at Midwest Research Institute through the office of Arid Lands Studies of the University of Arizona under the supervision of Edward Lawless of MRI and K.E. Focter of OALS. Funded by NSF, OALS is also sponsoring a systems analysis of the jojuba plantings on Indian lands in Arizona in conjunction with MRI (Ed Lawless, project leader). 
The OALS has submitted a proposal to NSF to coordinate guayule research reports at Tucson. The OALS efforts would be coordinated with the similar USDA effort.

At the University of Akron the NSF is supporting a study on the chemical composition of guayule resins. The NSF has also awarded a grant to the University of California, Riverside, to develop a tissue culture method for propagating jojoba.

\subsection{STATES}

California has contributed to the work on Euphorbia in the following ways: by furnishing building space and equipment for Calvin's laboratory at the Berkeley facility, by supporting a Euphorbia collection at Davis, and by establishing small field plots of Euphorbia in San Diego County through the various facilities of the University of California and the state Experiment Station.

In addition, the California Energy, Resources Conservation and Development Commission plans to expend about eight man-months on evaluation studies of guayule and Euphorbia.

Arizona, through its university and experiment station, has contributed funds, facilities, and manpower to the development of guayule, jojoba, and buffalo gourd as potential crops, especially for its arid lands.

Through its Natural Energy Institute, Hawaii has supported a project on developing diatoms as a source of energy to replace crude oil imports.

\subsection{OTHER SOURCES OF RESEARCH SUPPORT}

As part of a study on the deserts of North and South America, and because of the dominance of the crevsule bush, Larrea tridentata, in the Arizona and Mexican deserts, some $\$ 50,000$ over a six-year period has been devoted to the analysis of the cutractable materials frum Larrea at the University of Texas.

Firestone Tire and Rubber Co. has established observation plots of guayule near Fort Stockton, Tex., and plans to expand them eventually to 2,000 acres. A greenhouse has been constructed for experimental work on stand establishment, fertilizer, and water requirements. The area planted to date is estimated to be 100 acres. 
Firestone has also been studying methods of extracting and purifying the rubber from guayule, with emphasis on solvent extraction rather than on the old maceration-flotation method. An extraction mill is being built at Ft. Stockton.

Goodyear Rubber Company has established a small planting of guayule near Phoenix, Ariz., but is not planning a research program. Goodyear has also made an economic analysis of the cost of producing guayule rubber, including byproduct credits.

The hydrocarbons produced by plants have uses other than for rubber. Chemical companies such as Gulf Oil Research and Development Company, ARCO Chellical Company, and Swift Agricultural Chemlcal Company are taking a "look-see" attitude. They know of the studies on guayule, jojoba, and Euphorbia but are not working on the production, extraction, or purification of these pruducts.

One exception is the Diamond Shamrock Company of Painesville, Ohio, which is supporting work in the Office of Arid Land Studies, University of Arizona, to determine the climatic limitations of guayule, jojoba, Euphorbia, and some 40 additional desert plants that may contain compounds of value to the chemical industry.

Another instance where industry has taken an active interest in the development of plant hydrocarbons is the use of paraquat to increase oleoresin content of pine trees. The Ortho Division of the Chevron Chemical Company has supported some of these studles. Il lias also been possiblc to obtain cooperation from at least 20 companies thal grow pine trees in the eoutheastern region of the United States, in providing trees (Iand), equipment, and manpower for field studies.

Summaries of research support are presented in Tables 3-1 and 3-2. 
Table 3-1. SUMMARY OF ACTIVE OR RECENT HYDROCARBON SPECIES RESEARCH SUPPORT BY GOVERNMENT AND INDUSTRY

\begin{tabular}{lc}
\hline Agency & $\begin{array}{c}\text { Estimated Funding } \\
\text { Level }\end{array}$ \\
\hline Federal Government \\
Guayule Legislation (pending) \\
DOE & $\$ 30,000,000$ \\
USDA & 650,000 \\
NSF & 320,000 \\
IBRF & 610,000 \\
DOC & 50,000 \\
State of California & 300,000 \\
State of Arizona & $?$ \\
State of Hawaii & $?$ \\
Industry & $?$ \\
\hline
\end{tabular}

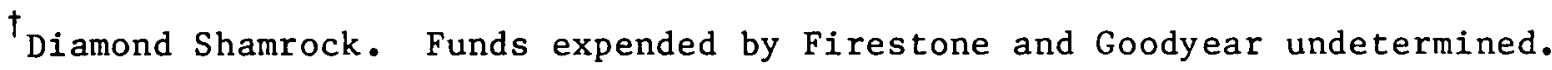


Iable 3-2.

AREAS OF RESEARCH ON HYDROCARBON SPECLES SUPPORTED BY GOVERNMENT AND INDUSTRY

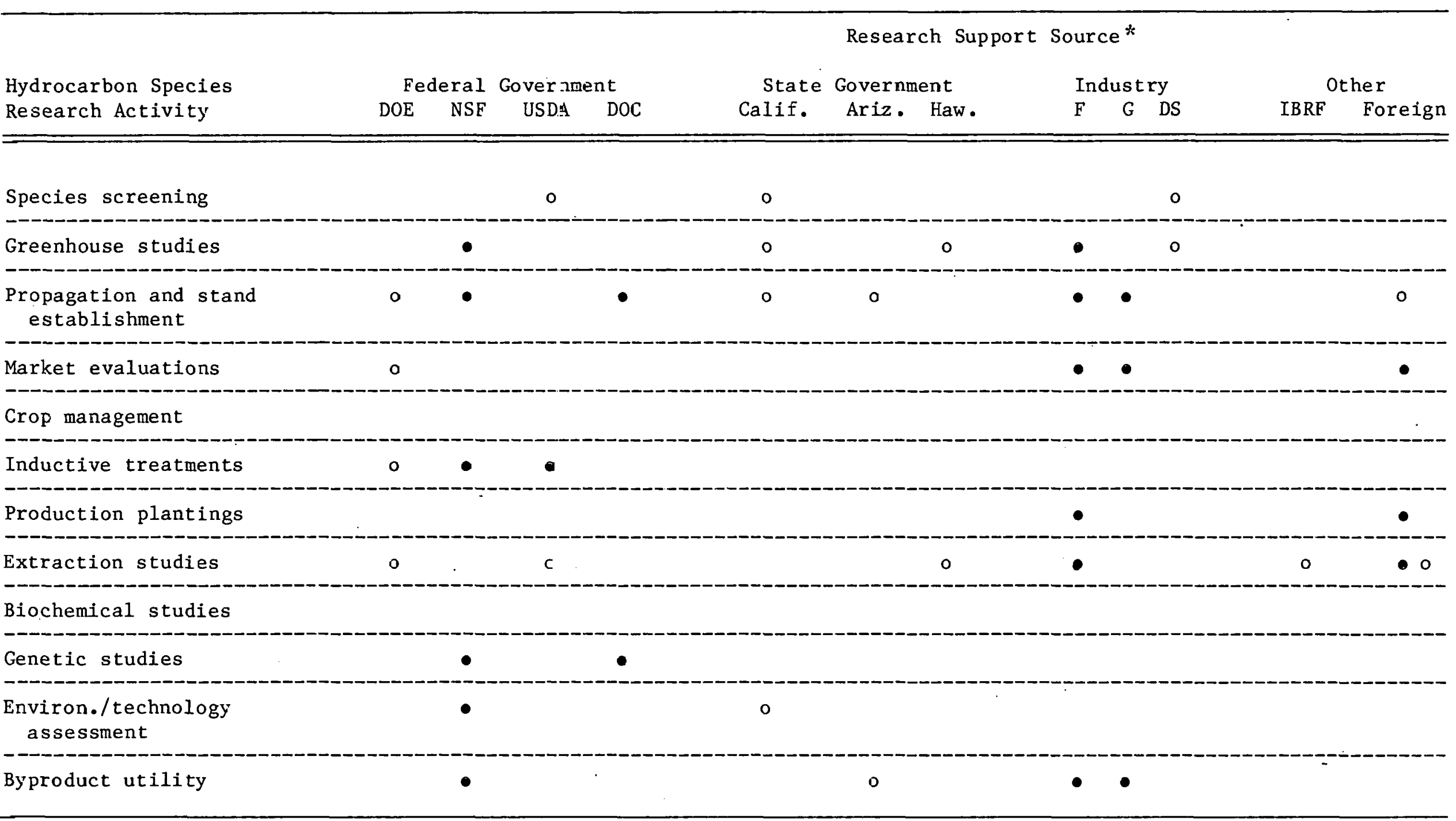

*DOE: U.S. Department of Energy, NSF: Naticnal Science Foundation, USDA: U.S. Department of Agriculture, DOC: U.S. Department of Commerce, $\Xi$ : Firestone Tire and Rubbər Company, G: Goodyear Rubber Company, DS: Diamond Shamrock Company, IBRF: International Biological Research Fund

- Research limited to guayule.

- Research on species other than guayule. 


\section{REFERENCES}

Anon. Guayule, an Alternative Source of Natural Rubber. National Academy of Sciences, Washington, D.C. (1977).

Anon. Products from Jojoba: A Promising New Crop for Arid Lands. National Academy of Sciences, Washington, D.C. (1975).

Anon. Underexploited Tropical Plants with Promising Economic Value: Buffalo Gourd. Adv. Comm. on Tech. Innov., National Academy of Sciences, Washington, D.C. (1975).

Bauman, A.J. Jet Propulsion Laboratory, Pasadena, Calif. Private communication (1978).

Bemis, W.P.; Berry, J.W.; and Weber, G.W. The Buffalo Gourd, a Potential Crop for Arid Lands. Arid Lands Newsletter No. 8, University of Arizona (June 1978).

Berlew, J.S. (ed.). Algae Culture: From Laboratory to Pilot Plant. Carnegie Inst. of Washington. Publ. No.600. Washington, D.C. (1953).

Buchanan, R.A. and Otey, F.H. Multi-U̇se Oil and Hydrocarbon-Producing Crops in Adaptive Systems for Food, Material, and Energy Production. Presented at International Conf. on Larrea: A Vast Resource of the American Desert. Saltillo, Mexico (Aug. 1978).

Buchanan, R.A., Otey, F.H.; Russell, C.A.; and Cull, I.M. Whole Plant Oils: Potential New Industrial Raw Materials. Presented at 69th Annual Meeting American 0il Chemical Soc., St. Louis (May 14-18, 1978).

Buchanan, R.A.; Swanson, C.L.; Weisleder, D.; and Cull, I.M. Gutta-Producing Grasses. Short Communication. Northern Reg. Research Center, USDA. Peoria, I11. (1978).

Buchanan, R.A., Cull, I.M.; Otey, F.H.; and Russell, C.R. Hydrocarbon and Rubber Producing Crops: Evaluation of 100 U.S. Plant Species. Presented at the 11 th Great Lakes Region Meeting. American Chemical Soc., Univ. of Wisc., Stevens Point, Wis. (1977). 
Buchanan, R.A.; Cull, I.M.; Otey, F.H.; and Russe11, C.R. Hydrocarbon and Rubber Producing Crops: Evaluation of U.S. Plant Species. Presented at the 110 th meeting, Rubber Div., Amer. Chem. Soc., San Francisco (Oct. 1976).

Calvin, M. Green Factories. Priestly Medal Address. Chem. Eng. News. (Mar. $20,1978)$.

Calvin, M. Hydrocarbons via Photosynthesis. Energy Research 1:299-327 (1977).

Calvin, H. Solar Energy by Photosynthesis. Science 184: 375-381 (1974).

Collier, T.J. Feasibility of Oleoresin Substitution for Petrochemicals. Report to ERDA. Contract EY-76-A-09-0903. Battelle Memorial Inst., Culumbus, Ohio (Aug. 1976).

Drew, J., and Roberts, D.R. Developments in Paraquat Treatments of Trees to Induce Lightwood Formation. For. Prod. J. 27:43-47 (1977).

Glymph, E.M., and Niven, J.J. Commercial Potent1al of Guayule. Presented at Rubber Conference. Washington, D.C. (June 1978).

Glymph, E.M. F1restone Natural Kubber and Latex Company. Private commulication (1978).

Hammond, B., and Polhamus, L.G. Research on Guayule (Parthenium argentatum), 1942-1959. Tech. Bul1. No. 1327. ARS/USDA, Washington, D.C. (1965).

Hansen G.P. Progress Report. National Science Foundation. Grant No. AER 7624472.

Hinman, C.L. Diamond Shamrock Co., Palnesville, Ohlu. Piivate communication (1978).

Mabry, T.J. Larrea: A Chemical Resource. Presented at International Conference on Larrea: A Vast Resource of the American Deserts. Saltillo, Mexico (Aug. 1978).

Mabry, T. Dept. of Botany, Univ. of Texas. Private communication (1978). 
McGinnies, W.; Foster, K.; and Brooks, W. Office of Arid Land Studies, University of Arizona. Private communication (1978).

Myers, L.E. Agricultural Research Service, USDA, Tucson, Ariz. Private communication (1978).

Nielsen, P.E., Nishimura, H.; Otvos, J.W.; and Calvin, M. Plant Crops as a Source of Fuel and Hydrocarbon-1ike Materials. Science 198: 942-944 (1977).

Otvos, J. Chemical Biodynamics Laboratory, University of California, Berkeley. Draft report to U.S. Dept. of Energy (May 1978).

Raymond, L.P. Initial Investigations on a Shallow Layer Algae Production System. Hawaiian Natural Energy Inst., Hawaii. (Feb. 1977).

Rubis, D.0. Univ, of Arizona. Private communication (1978).

Schechter, J. Experimental Guayule Plantings in Israel. Proc. Ist International Conference on Utility of Guayule, Tucson, Ariz. (1975).

Sherbrooke, W.C. and Haase, E.F. Jojoba: A Wax-Producing Shrub of the Sonoran Desert. Arid Lands Resource Information Paper No. 5. Off. Arid Land Studies, Univ. of Arizona. Tucson, Ariz. (1976).

Stubblefield, T.M. and Wright, N.G. Estimated Costs and Returns for Producing Jojoba on the Indian Reservations in Arizona and California. Jojoba Happenings 19:3-14 (1977).

Stubbs, J. Fuel Plantation Research. Progress Reports for Aug/Dec, 1977. Southwestern Forest Experimental Stat1on, U.S. Forest Service, Aiken, S.C. (1977).

Weber, E.J. Jojoba on the Other Side of the Globe. Jojoba Happenings, No. 23 (1977).

Winkler, D. University of Akron. Institute of Polymer Science. Private communication (1978).

Wright, H.G. Buffalo Gourd Development Costs. Univ. of Arizona (1974). 
Yokoyama, H., Hagman, E.P.; Hsu, W.J.; Poling, S.M.; and Bauman, A.J. Chemical Bioinduction of Rubber in Guayule Plants. Science 197: 1076-1078 (1978).

Yokoyama, H. USDA Fruit and Vegetable Chemistry Laboratory, Pasadena, Calif. Private communication (1978). 


\section{DISTRIBUTION LIST}

No. of Copies

$-1$

1

1

2

1

2

1

1

1

1
Distribution

Department of Energy:

DOE, SERI Site office

Contracting officer

Attn: Charles H. Skinner

Chicago Operations office

Interim Program Division

Attn: M. E. Jackson

Division of Solar. Technology

Office of Asst. Director for Adninistration

Attn: R. H. Annan

Office of Asst. Secretary for Conservation

\& Solar Applications

Attn: R. Scott

Office of Solar, Geothermal Electric \&

Storage Programs

Attn: H. H. Marvin

Division of Energy Technology

Administration

Attn: S. Hansen

Division of Distributed Solar Technology

Office of the Director

Attn: R. San Martin

Division of Central Solar Technology

Office of the Director

Attn: H. Coleman

Division of Energy Storage Systems

Office of the Director

Attn: G. Pezdirtz

Division of Planning \& Energy Transfer

Office of the Director

Attn: M. Adams 